\title{
JURNAAL

\section{Pengaruh Distributive Justice dan Procedural Justice Terhadap Employee Engagement pada PT. X dengan Affective Commitment sebagai Variabel Mediasi}

(The Influence of Distributive Justice and Procedural Justice on Employee Engagement at PT. X with Affective Commitment as a Mediation Variable)

Rosalia Fatma Bamiati

Program Studi Magister Manajemen Universitas Airlangga Surabaya ocha.ocha64@gmail.com

\section{Info Artikel}

Diterima Agustus 1, 2020

Direvisi Agustus 20, 2020

Dipubikasi September 20, 2020

\section{Kata Kunci: \\ employee engagement, distributive justice, procedural justice, affective commitment}

\begin{abstract}
Abstrak
PT. X merupakan perusahaan industri terminal kargo curah cair yang berdiri sejak tanggal 23 Agustus 2013 dan berlokasi di Pelabuhan Tanjung Perak, namun PT X baru beroperasional secara penuh pada awal tahun 2018. Tingkat engaged PT. $\mathrm{X}$ masih rendah, Hal ini dapat dilihat dari persentase absensi dan persentase turnover karyawan yang terus meningkat. Menurut Markos dan Sridevi (2010), perusahaan dengan karyawan yang disengaged akan mengalami peningkatan tingkat absensi dan juga akan mempengaruhi tingkat turnover dalam perusahaan. Colquitt (2001) menerangkan organizational justice dalam tiga hal yaitu: distributive justice, procedural justice, dan interactional justice. Dalam penelitian ini akan dibahas tentang procedural justice dan distributive justice. Hal ini disebabkan dalam dimensi keamanan yang diidentifikasikan oleh Kahn (1990) melibatkan situasi sosial yang dapat diprediksi dan konsisten. Menurut Allen dan Meyer affective commitment mengacu kepada keterikatan emosional karyawan terhadap organisasi. Saks (2006) menemukan bahwa employee engagement berpengaruh signifikan terhadap komitmen organisasional. Tujuan penelitian ini adalah menganalisa pengaruh distributive justice dan procedural justice terhadap employee engagement pada PT.X melalui affective commitment sebagai variabel mediasi. Populasi pada penelitian ini sejumlah 66 karyawan tetap dan menggunakan
\end{abstract}


Keywords : Employee engagement, Distributive justice, justice, Procedural commitment metode sampling jenuh. Teknik analisis menggunakan Partial Least Square (PLS).

\section{PENDAHULUAN}

Employee engagement merupakan salah satu cara untuk membuat karyawan memiliki loyalitas yang tinggi, dimana Macey dan Schneider (2008: 4) menyatakan bahwa employee engagement membuat karyawan memiliki loyalitas yang lebih tinggi sehingga mengurangi keinginan untuk meninggalkan perusahaan secara sukarela. Employee engagement yang tinggi ditunjukan dalam say, stay, dan strive oleh karyawan (Yulianti, 2016). Say merupakan perkataan positif karyawan tentang organisasi pada 
rekan kerja, karyawan potensial maupun konsumen. Stay diwujudkan dengan sikap memiliki organisasi yang kuat dan keinginan untuk terus menjadi anggota dalam organisasi serta strive merupakan perilaku karyawan yang selalu termotivasi dan berusaha untuk meraih kesuksesan baik dalam pekerjaan maupun untuk organisasi.

Berdasar hasil penelitian yang dirilis dari Gallup (2017) terkait employee enggagement terhadap 155 negara mulai dari tahun 2014 - 2016 menunjukkan bahwa hanya $15 \%$ karyawan di seluruh dunia yang engaged terhadap pekerjaannya, $67 \%$ not engaged dan $18 \%$ actively disengaged. Di antara delapan negara di Asia Tenggara yang di lakukan survey, menunjukkan bahwa Indonesia berada pada posisi dua terendah yaitu $15 \%$. Masih banyak karyawan di perusahaan yang ada di Indonesia yang disengaged terhadap perusahaan dan PT X termasuk salah satunya.

PT. X merupakan perusahaan industri terminal kargo curah cair yang berdiri sejak tanggal 23 Agustus 2013 dan berlokasi di Pelabuhan Tanjung Perak, namun PT X baru beroperasional secara penuh pada awal tahun 2018. PT X merupakan joint venture dari anak perusahaan BUMN yang bergerak dibidang pelabuhan dengan anak perusahaan Swasta yang bergerak di bidang curah cair. Karena PT X baru beroperasional awal tahun 2018, PT X dituntut memiliki sumber daya manusia dengan kualitas yang bagus guna mengahadapi persaingan dengan perusahaan lain pada bidang serupa. Oleh karena itu employee engagement sangat diperlukan untuk meningkatkan produktivitas karyawan dan agar bisa bersaing dengan kompetitor di bidang serupa di wilayah yang sama. Namun pada kondisi sekarang ini, tingkat engaged PT. X masih rendah. Hal ini dapat dilihat dari prosentase absensi dan prosentase turnover karyawan. Menurut Markos dan Sridevi (2010), perusahaan dengan karyawan yang disengaged akan mengalami peningkatan tingkat absensi dan juga akan mempengaruhi tingkat turnover dalam perusahaan. Pada grafik dibawah ini, dapat dilihat bahwa ada kenaikan prosentase absensi dan prosesntase turnover karyawan tiap tahunnya.

\section{Turn Over Karyawan PT.X}

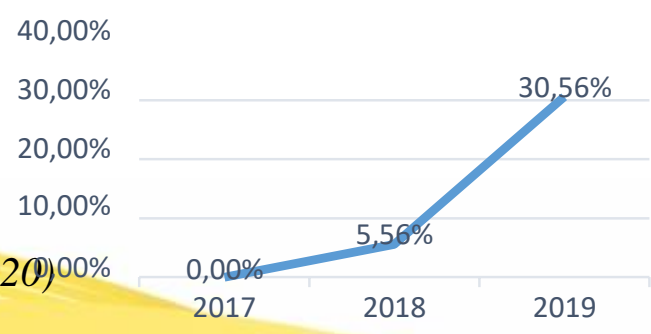




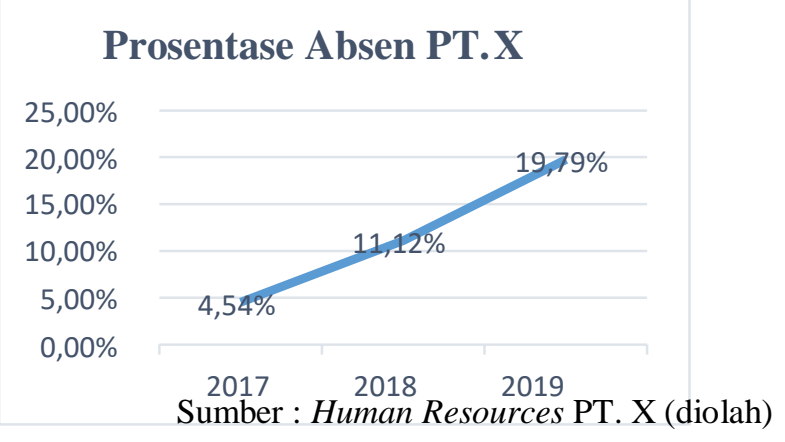

Gambar 1 Grafik Prosentase Absensi dan Prosentase Turnover Karyawan PT.X

Menurut hasil exit interview, 61,54\% karyawan resign karena tawaran dari perusahaan lain lebih menggiurkan dari segi komponen gaji, jenjang karir dan juga lebih sesuai dengan passion kerja mereka. Basic Salary untuk karyawan di level staff atau operator sudah memenuhi standar Upah Minimum Kabupaten (UMK), namun untuk kenaikan gaji tiap tahun masih belum berdasarkan performance masing-masing karyawan karena belum ada Key Performance Indicator (KPI) ataupun tools lain yang objektif untuk menilai. Sehingga kenaikan gaji masing- masing karyawan belum memiliki landasan yang obyektif dan bisa menyebabkan ketidakadilan yang dilakukan oleh perusahaan kepada karyawannya

Colquitt (2001) menerangkan organizational justice dalam tiga hal yaitu: distributive justice, procedural justice, dan interactional justice. Dalam penelitian ini akan dibahas tentang procedural justice dan distributive justice. Hal ini disebabkan dalam dimensi keamanan yang diidentifikasikan oleh Kahn (1990) melibatkan situasi 
sosial yang dapat diprediksi dan konsisten.

Permasalahan yang ada pada PT. X bila dikaitkan dengan keadilan organisai yang dikemukakan oleh Colquit (2001), dinilai dari keadilan distributif yang berdasarkan teori equity berfokus terhadap masukan (input) dan hasil (outcomes). Input dideskripsikan sebagai segala sesuatu yang seseorang anggap sebagai kontribusinya terhadap pertukaran dimana seseorang mengharapkan sebuah timbal balik yang seimbang. Sedangkan outcomes dideskripsikan sebagai reward yang diterima oleh individu dari pertukaran tersebut. Selanjutnya, bila dikaitkan keadilan prosedural, menurut Greenberg (1993) keadilan prosedural adalah persepsi keadilan tentang kebijakan dan prosedur yang digunakan untuk membuat keputusan dimana para karyawan PT. X yang mempertanyakan kebijakan prosedur saat penambahan beban kerja dilakukan.

Allen dan Meyer (1990) membagi komitmen organisasional menjadi tiga dimensi: affective, continuance, dan normative. Menurut Allen dan Meyer affective commitment mengacu kepada keterikatan emosional karyawan terhadap organisasi. Saks (2006) menemukan bahwa employee engagement berpengaruh signifikan terhadap komitmen organisasional. Selanjutnya, pada analisis mediasi ditemukan bahwa employee engagement memediasi secara parsial hubungan procedural dan distibutive justice terhadap komitmen organisasional.

Sampai sekarang PT X masih terus melakukan rekrutmen untuk memenuhi kebutuhan sumber daya manusia yang diperlukan. Karyawan yang di rekrut sebagian besar adalah karyawan yang sudah memiliki pengalaman dengan tujuan supaya perusahaan dapat berjalan dengan segera tanpa harus melakukan training pada karyawan baru dan dapat merancang sistem kerja pada departemen masing- masing. Total karyawan PT X sebanyak 72 orang dengan komposisi 24karyawan fresh graduate dan 48 karyawan sudah berpengalaman. Karena perusahaan masih baru beroperasional maka affective commitment sangat diperlukan sekali untuk menimbulkan sikap positif karyawan terhadap perusahaan serta memunculkan rasa memiliki. Hal ini dapat timbul didasarkan pada keinginan dari diri karyawan yang disebabkan oleh rasa keterikatan emosional dengan perusahaan dan hal ini dapat menimbulkan rasa engage terhadap pekerjaan dan 
perusahaan. Disamping itu juga sangat diperlukan agar perusahaan bisa terus berkembang.

Pada penelitian ini membahas mengenai pengaruh distributive justice dan procedural justice terhadap employe engagement pada PT. X dengan affective commitment sebagai variabel mediasi. Objek dalam penelitian ini adalah karyawan tetap / permanen PT. X sejumlah 66 karyawan.

\section{METODE PENELITIAN}

Model Penelitian

H1

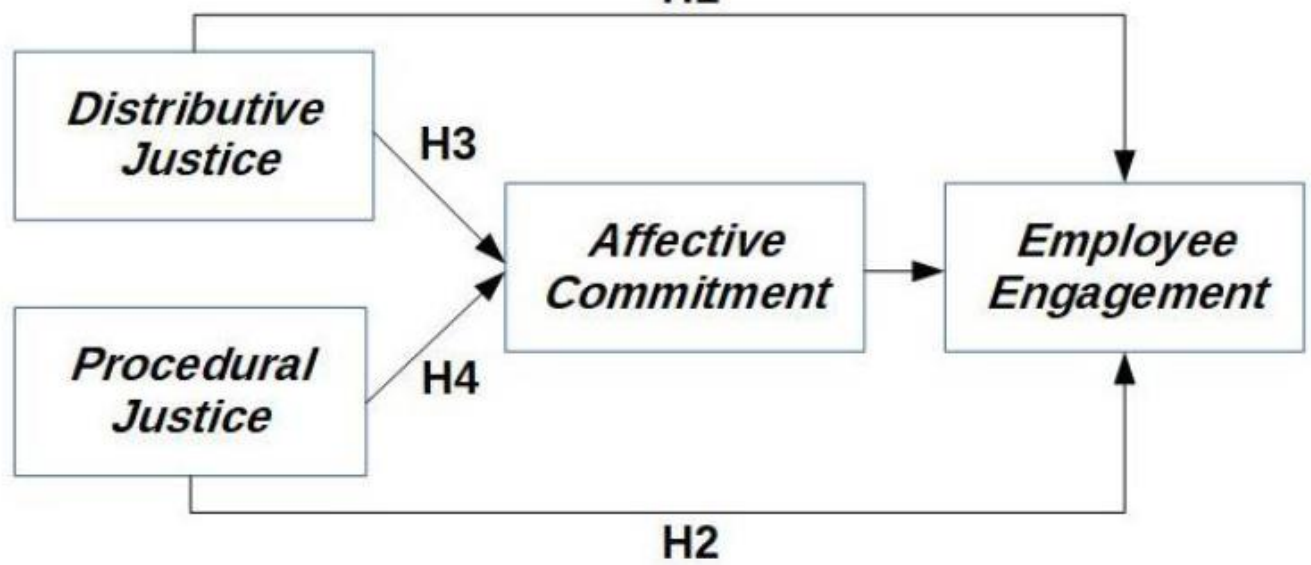

Populasi

Populasi dalam penelitian ini adalah karyawan PT. X dengan jumlah karyawan sebanyak 66 orang karyawan tetap. Seluruh populasi dijadikan responden karena jumlahnya yang tidak terlalu besar

Sampel

Metode pengambilan sampel dari seluruh anggota populasi disebut metode sensus atau sampling jenuh (Sugiyono, 2013: 32).

Definisi Operasional Variabel 
Variabel yang digunakan dalam penelitian akan diidentifikasikan agar mampu untuk dioperasionalkan serta dapat diukur menggunakan instrument atau alat ukur. Berikut adalah definisi operasional dari variabel-variabel yang akan diteliti

Distributive Justice sebagai variabel independen (X1)

Distributive Justice (X1) menurut Colquitt et al. (2001) berkaitan dengan alokasi atau hasil yang diperoleh karyawan di tempat kerja sesuai dengan tujuan organisasi. Distributive justice juga menyangkut tentang persepsi karyawan terhadap keadilan dari hasil alokasi tersebut. Berikut empat indikator yang digunakan untuk mengukur distributive justice menurut Colquit (2001)

1. Kesesuaian hasil yang diperoleh merefleksikan usaha yang dikeluarkan dalam pekerjaan

2. Kesesuaian hasil yang diperoleh terhadap pekerjaan yang telah diselesaikan

3. Kesesuaian hasil merefleksikan kontribusi yang diberikan kepada perusahaan

4. Kesesuaian hasil terhadap performa yang diberikan kepada perusahaan

Procedural Justice sebagai variabel independen (X2)

Procedural Justice (X2) merupakan persepsi karyawan terhadap prosedurprosedur yang digunakan oleh perusahaan untuk mendistribusikan hasil dan sumber daya organisasi. Berikut tujuh indikator yang digunakan untuk mengukur procedural justice menurut Colquit (2001)

1. Prosedur diimplementasikan secara konsisten.

2. Prosedur yang digunakan tidak bias.

3. Prosedur berdasarkan informasi yang akurat.

4. Prosedur melibatkan semua pihak.

5. Prosedur bertujuan untuk memperbaiki kesalahan.

Affective Commitment sebagai variabel mediasi (Z)

Affective Commitment adalah keterlibatan emosional seseorang pada organisasinya berupa perasan cinta pada organisasi. Untuk mengukur komitmen organisasi yang terdiri dari tiga komponen, Meyer dan Allen (1997) telah beberapa 
kali menggunakan Organizational Commitment Questionnaire (OCQ) yang dikhususkan untuk mengukur Affective Commitment. Affective Commitment diukur dengan pernyataan :

1. Responden senang menghabiskan sisa karir di perusahaan ini.

2 Responden senang mendiskusikan terkait perusahaan dengan orangorang di luar perusahaan.

3. Responden merasa seolah-olah masalah yang ada di perusahaan adalah masalah pribadi.

4. Responden tidak akan mudah terikat dengan perusahaan lain seperti pada termpat kerja saat ini.

5. Responden merasa seperti sebagai "bagian dari keluarga" dari perusahaan.

6. Responden merasa terikat secara emosional dengan perusahaan.

7. Responden bekerja di perusahaan ini sangat berarti bagi nilai pribadi.

8. Responden mempunyai perasaan memiliki yang kuat terhadapperusahaan

Employe Engagement sebagai variabel dependent (Y)

Employee engagement karyawan PT X terhadap pekerjaan dapat diukur menggunakan tiga dimensi meliputi vigor, dedication, dan absorption dengan sembilan indikator berdasarkan Utrecht Work Engagement Scale (Yulianti, 2016), yaitu:

\section{a. Dimensi Vigor diukur dengan item pernyataan:}

1. Di tempat kerja merasa dipenuhi dengan energi.

2. Dalam mengerjakan pekerjaan secara mental merasa sangat tangguh.

3. Di tempat kerja selalu bertahan, bahkan saat sesuatu tidak berjalan dengan semestinya.

\section{b. Dimensi Dedication diukur dengan item pernyataan:}

1. Pekerjaan penuh makna dan tujuan.

2. Pekerjaan mampu menginspirasi. 


\section{JURNA A

3. Pekerjaan memberikan tantangan.

c. Dimensi Absorption diukur dengan item pernyataan:

1. Waktu cepat berlalu ketika sedang bekerja.

2. Sering larut dalam pekerjaan.

3. Sulit melepaskan diri dari pekerjaan

HASIL DAN PEMBAHASAN

Tabel Profil Responden

\begin{tabular}{|c|c|c|c|}
\hline \multicolumn{4}{|c|}{ Jenis Kelamin } \\
\hline No & Jenis Kelamin & Jumlah & Persentase $(\%)$ \\
\hline 1 & Laki - Laki & 48 & $72,7 \%$ \\
\hline 2 & Perempuan & 18 & $27,3 \%$ \\
\hline \multicolumn{4}{|c|}{ Usia } \\
\hline No & Usia & Jumlah & Persentase $(\%)$ \\
\hline 1 & $20-25$ Tahun & 15 & $22,7 \%$ \\
\hline 2 & $26-30$ Tahun & 27 & $40,9 \%$ \\
\hline 3 & $31-35$ Tahun & 18 & $27,3 \%$ \\
\hline 4 & $36-40$ Tahun & 6 & $9,1 \%$ \\
\hline \multicolumn{4}{|c|}{ Profil Departemen/Divisi } \\
\hline 1 & Commercial & 3 & $4,5 \%$ \\
\hline 2 & Finance \& Accounting & 9 & $13,6 \%$ \\
\hline 3 & HR \&GA & 12 & $18,2 \%$ \\
\hline 4 & Maintenance & 6 & $9,1 \%$ \\
\hline 5 & Operation & 33 & $50,0 \%$ \\
\hline 6 & SHE & 3 & $4,5 \%$ \\
\hline \multicolumn{4}{|c|}{ Profil Kualifikasi Pendidikan } \\
\hline 1 & SLTA & 3 & $4,5 \%$ \\
\hline 2 & D3 & 21 & $31,8 \%$ \\
\hline 3 & S1 & 42 & $63,6 \%$ \\
\hline
\end{tabular}




\begin{tabular}{|c|l|c|c|}
\hline \multicolumn{4}{|c|}{ Lama Menjabat } \\
\hline 1 & $<1$ Tahun & 30 & $45,5 \%$ \\
\hline 2 & $1-2$ Tahun & 30 & $45,5 \%$ \\
\hline 3 & $2-3$ Tahun & 6 & $9,0 \%$ \\
\hline \multicolumn{3}{|c|}{ Status Pernikahan } \\
\hline 1 & Belum Menikah & 12 & $18,2 \%$ \\
\hline 2 & Menikah & 54 & $81,8 \%$ \\
\hline \multicolumn{4}{|c|}{ Gaji } \\
\hline 1 & Rp. 3 Juta - Rp. 6 Juta & 39 & $59,1 \%$ \\
\hline 2 & Rp. 6 Juta - Rp. 9 Juta & 18 & $27,3 \%$ \\
\hline 3 & Rp. 9 Juta - Rp. 12 Juta & 3 & $4,5 \%$ \\
\hline 4 & $>$ Rp. 12 Juta & 6 & $9,1 \%$ \\
\hline
\end{tabular}

Analisis data yang dipergunakan untuk membuktikan hipotesis dalam penelitian ini adalah metode statistik SEM Partial Least Square (PLS) menggunakan Smart PLS 3.2.9. Model struktural partial least square penelitian disusun berdasarkan pengukuran gabungan first order pada 3 variabel yaitu distributive justice, procedural justice dan affective commitment, sementara itu pengukuran second order dipergunakan untuk variabel employee engagement yang terdiri atas 3 dimensi yaitu vigor, dedication dan absorption. Penyusunan model struktural gabungan antara first order dan second order dapat ditampilkan pada Gambar sebagai berikut:

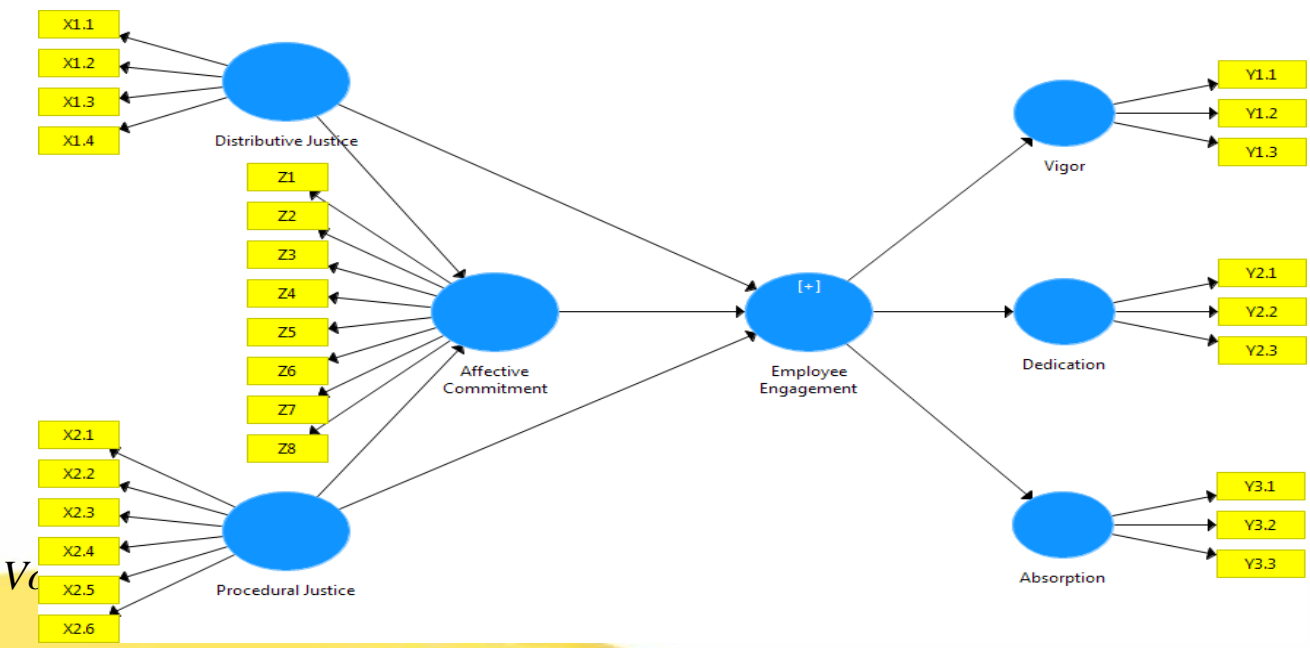


Dalam mengevaluasi outer model adalah dengan melakukan pengukuran measurement model pada variabel-variabel penelitian. Evaluasi yang dilakukan meliputi pengujian convergent validity, discriminant validity dan composite reliability.

\section{a. Convergent Validity}

Pengukuran convergent validity menggunakan nilai outer loading dengan batas ketentuan nilai outer loading adalah lebih besar dari 0,5. Berikut ini adalah hasil estimasi nilai outer loading dan average variance extracted pada setiap variabel penelitian dalam model struktural:

Tabel 2. Nilai Outer Loading \& AVE Model Struktural

\begin{tabular}{|c|c|c|c|}
\hline Variabel & $\begin{array}{l}\text { Indikato } \\
\mathrm{r}\end{array}$ & $\begin{array}{c}\text { Nilai Outer } \\
\text { Loading }\end{array}$ & $\begin{array}{l}\text { Average } \\
\text { Variance } \\
\text { Extracted (AVE) }\end{array}$ \\
\hline \multirow{4}{*}{$\begin{array}{l}\text { Distributive } \\
\text { Justice }\end{array}$} & X1.1 & 0,909 & \multirow{4}{*}{0,814} \\
\hline & $\mathrm{X} 1.2$ & 0,969 & \\
\hline & $\mathrm{X} 1.3$ & 0,873 & \\
\hline & $\mathrm{X} 1.4$ & 0,854 & \\
\hline \multirow{6}{*}{$\begin{array}{l}\text { Procedural } \\
\text { Justice }\end{array}$} & $\mathrm{X} 2.1$ & 0,812 & \multirow{6}{*}{0,625} \\
\hline & $\mathrm{X} 2.2$ & 0,707 & \\
\hline & $\mathrm{X} 2.3$ & 0,749 & \\
\hline & $\mathrm{X} 2.4$ & 0,771 & \\
\hline & $\mathrm{X} 2.5$ & 0,839 & \\
\hline & $\mathrm{X} 2.6$ & 0,856 & \\
\hline
\end{tabular}




\begin{tabular}{|c|c|c|c|}
\hline \multirow{8}{*}{$\begin{array}{r}\text { Affective } \\
\text { Commitment }\end{array}$} & $\mathrm{Z1}$ & 0,898 & \multirow{8}{*}{0,724} \\
\hline & $\mathrm{Z} 2$ & 0,810 & \\
\hline & $\mathrm{Z} 3$ & 0,732 & \\
\hline & $\mathrm{Z} 4$ & 0,871 & \\
\hline & $\mathrm{Z5}$ & 0,775 & \\
\hline & Z6 & 0,898 & \\
\hline & $\mathrm{Z7}$ & 0,897 & \\
\hline & Z8 & 0,908 & \\
\hline & Y1.1 & 0,895 & \\
\hline $\begin{array}{l}\text { Niat Pembelian } \\
\text { Ulang }\end{array}$ & & & 0,679 \\
\hline
\end{tabular}

\section{b. Discriminant Validity}

Setelah dilakukan evaluasi convergent validity, selanjutnya adalah mengevaluasi discriminant validity yang meggunakan evaluasi fornell-larcker sebagai pengukurnya.

Tabel 3. Evaluasi Fornell-Larcker Criteriom

\begin{tabular}{|l|c|c|c|c|}
\hline \multicolumn{1}{|c|}{ Variabel } & $\begin{array}{c}\text { Distributive } \\
\text { Justice }\end{array}$ & $\begin{array}{c}\text { Procedural } \\
\text { Justice }\end{array}$ & $\begin{array}{c}\text { Affective } \\
\text { Commitment }\end{array}$ & $\begin{array}{c}\text { Employee } \\
\text { Engagement }\end{array}$ \\
\hline Distributive Justice & $\mathbf{0 , 9 0 2}^{\mathrm{a}}$ & & & \\
\hline Procedural Justice & $0,600^{\mathrm{b}}$ & $\mathbf{0 , 7 9 1}^{\mathrm{a}}$ & & \\
\hline Affective Commitment & $0,616^{\mathrm{b}}$ & $0,650^{\mathrm{b}}$ & $\mathbf{0 , 8 5 1}^{\mathbf{a}}$ & \\
\hline Employee Engagement & $0,545^{\mathrm{b}}$ & $0,643^{\mathrm{b}}$ & $0,800^{\mathrm{b}}$ & $\mathbf{0 , 8 2 4}^{\mathrm{a}}$ \\
\hline
\end{tabular}

Keterangan: a : Akar AVE

b : Korelasi Antar Variabel 
Berdasarkan pada Tabel evaluasi Formell-Larcker menunjukkan bahwa nilai akar AVE setiap variabel penelitian yang berada pada baris diagonal sudah memiliki nilai koefisien yang lebih besar dibandingkan dengan korelasi yang terjadi antar variabel penelitian. Dengan demikian, dari hasil evaluasi Fornel-Larcker ini disimpulkan bahwa evaluasi discriminant validity dari analisis PLS sudah dapat terpenuhi.

\section{c. $\quad$ Composite Reliability}

Evaluasi terakhir pada outer model adalah composite reliability yang menguji nilai reliabilitas pada masing-masing indikator dalam suatu variabel. Suatu variabel dikatakan telah memenuhi composite reliability apabila nilai composite reliability serta nilai cronbach alpha lebih besar nilainya dari 0,7 . Berikut ini merupakan nilai composite reliability pada masing-masing variabel.

Tabel 4.Nilai Composte Reliability dan Cronbach Alpha

\begin{tabular}{|l|c|c|}
\hline \multicolumn{1}{|c|}{ Variabel } & $\begin{array}{c}\text { Composite } \\
\text { Reliability }\end{array}$ & $\begin{array}{c}\text { Cronbach } \\
\text { Alpha }\end{array}$ \\
\hline Distributive Justice & 0,946 & 0,924 \\
\hline Procedural Justice & 0,909 & 0,883 \\
\hline Affective Commitment & 0,954 & 0,945 \\
\hline Employee Engagement & 0,950 & 0,939 \\
\hline
\end{tabular}

Berdasarkan Tabel diatas terlihat bahwa setiap variabel dalam model penelitian memiliki nilai composite reliability yang lebih besar dari 0,7. Sementara itu, untuk nilai cronbach alpha juga diperoleh nilai yang kesemuanya lebih besar dari 0,70. Mengacu pada hasil evaluasi ini, maka dapat disimpulkan bahwa pada masing- masing variabel penelitian telah memenuhi composite reliability.

\section{Evaluasi Inner Model}

Pada evaluasi inner model akan dijelaskan uraian pada hasil $R$-square dan pengujian hipotesis penelitian yang dikembangkan dalam model struktural. Hasil dari estimasi bootstrapping model struktural dengan Smart PLS 3.2.9 adalah sebagai berikut: 


\section{JURNAL EKBIS \\ ANALISIS, PREDIKSI, DAN INFORMASI} sinta

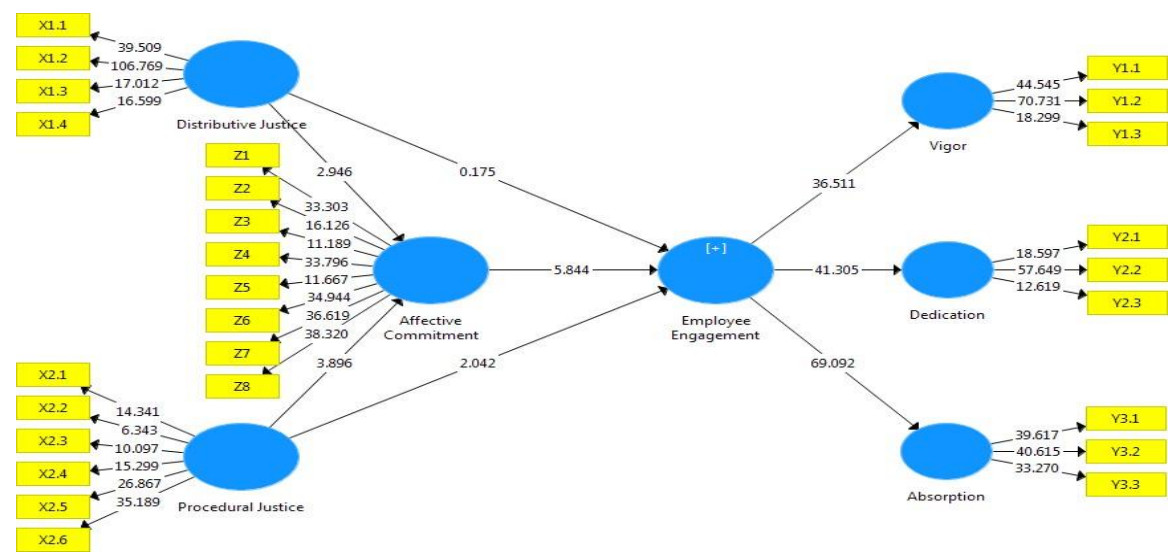

Gambar2. Hasil Estimasi Bootstrapping Smart PLS 2

\section{R-Square}

Pada penilaian goodness of fit ini adalah dengan melihat nilai $R$-square yang dihasilkan melalui estimasi Smart PLS pada setiap jalur. Berdasarkan pengolahan data dengan metode PLS diperoleh $R$-square sebagai berikut.

Tabel 5. Nilai $R$-square

\begin{tabular}{|c|c|}
\hline Variabel & $R$ \\
& Square \\
\hline Affective Commitment & 0,50 \\
& 2 \\
\hline Employee Engagement & 0,66 \\
\hline
\end{tabular}

Jalur hubungan pada model struktural antara variabel distributive justice dan procedural justice terhadap affective commitment diperoleh nilai $R$-square sebesar 0,502 yang memiliki arti bahwa persentase keragaman persepsi affective commitment yang diberikan oleh karyawan PT X dapat dijelaskan oleh persepsi pada variabel distributive justice dan procedural justice sebesar 50,2\%. 
Sementara jalur hubungan pada model strktural antara distributive justice, procedural justice dan affective commitment terhadap employee engagement diperoleh nilai $R$-square sebesar 0,666 yang memberikan arti bahwa persentase keragaman persepsi karyawan PT X mengenai atas employee engagement dapat dijelaskan oleh persepsinya pada variabel distributive justice, procedural justice dan affective commitment sebesar $66,6 \%$.

Dari dua nilai $\mathrm{R}$ Square yang diperoleh dapat dihitung nilai koefisien dtereminasi total R-Square total dengan formula $\mathrm{R}^{2}$ total $=1-\left(\mathrm{P}_{\mathrm{e} 1}^{2} \times \mathrm{P}_{\mathrm{e} 2}^{2}\right)$.

$$
\mathrm{P}_{\mathrm{ei}}=\sqrt{1-R i^{2}}=\left(1-\mathrm{Ri}^{2}\right)^{0.5} \text {. }
$$

Berdasarkan hasil analisis diperoleh $\mathrm{R}_{1}{ }^{2}=0,502$ dan nilai $\mathrm{R}_{2}^{2}=0,666$ sehingga diperoleh nilai $\mathrm{P}_{\mathrm{e} 1}$ dan $\mathrm{P}_{\mathrm{e} 2}$ sebagai berikut:

$\mathrm{P}_{\mathrm{e} 1}^{2}=(1-0,502)^{0.5}=0,498$

$\mathrm{P}_{\mathrm{e} 2}{ }^{2}=(1-0,666)^{0.5}=0,334$

Didapat nilai koefisien determinasi total sebagai berikut:

$\mathrm{R}^{2}$ total $=1-\left(\mathrm{P}_{\mathrm{e} 1}^{2} \times \mathrm{P}_{\mathrm{e} 2}{ }^{2}\right)$

$\mathrm{R}^{2}$ total $=1-(0,498 \times 0,334)$

$\mathrm{R}^{2}$ total $=1-0,166=0,834$

Hasil perhitungan diperoleh nilai $\mathrm{R}^{2}$ total sebesar 0,834 yang menunjukkan bahwa keragaman persepsi karyawan pada setiap variabel penelitian di model struktural dalam mengungkap fenomena employee engagement yang ada di PT X sebesar $83,4 \%$ sedangkan sisanya sebesar $16,6 \%$ dijelaskan oleh variabel lain yang tidak digunakan dalam model.

\section{a. Inner Weight}

Evaluasi inner weight dipergunakan untuk melakukan pengujian atas hipotesis penelitian yang telah dirumuskan. Hasil dari pengujian hipotesis penelitian berdasarkan evaluasi inner weight adalah sebagai berikut:

Tabel Pengaruh Langsung (Direct Effect) 


\begin{tabular}{|l|c|c|c|c|}
\hline \multicolumn{1}{|c|}{ Direct Effect } & $\begin{array}{c}\text { Original } \\
\text { Sample }\end{array}$ & T-statistic & p-value & Keterangan \\
\hline $\begin{array}{l}\text { Distributive Justive } \rightarrow \\
\text { Affective Commitment }\end{array}$ & 0,353 & 2,946 & 0,003 & Signifikan \\
\hline $\begin{array}{l}\text { Procedural Justive } \rightarrow \\
\text { Affective Commitment }\end{array}$ & 0,438 & 3,896 & 0,000 & Signifikan \\
\hline $\begin{array}{l}\text { Affective Commitment } \rightarrow \\
\text { Employee Engagement }\end{array}$ & 0,654 & 5,844 & 0,000 & Signifikan \\
\hline $\begin{array}{l}\text { Distributive Justice } \rightarrow \\
\text { Employee Engagement }\end{array}$ & 0,018 & 0,175 & 0,861 & \begin{tabular}{c} 
Tidak \\
\hline $\begin{array}{l}\text { Procedural Justice } \rightarrow \\
\text { Employee Engagement }\end{array}$
\end{tabular} \\
\hline
\end{tabular}

\section{Hipotesis I}

Hasil estimasi pada jalur pengaruh antara Distributive Justice terhadap Employee Engagement diperoleh nilai path coefficients sebesar 0,0183 yang memiliki arah positif. Sementara itu, nilai t-values pada jalur Distributive Justice terhadap Employee Engagement diperoleh nilai 0,175 dengan nilai p-values sebesar 0,861. Berdasarkan hasil tersebut, diketahui bahwa nilai $t$-values $0,175<1,96$ dan nilai $p$-values $0,861>0,05$ maka dapat disimpulkan bahwa terdapat pengaruh positif yang tidak signifikan antara variabel Distributive Justice terhadap Employee Engagement pada PT X di Surabaya. Dengan demikian hipotesis pertama penelitian $\left(\mathrm{H}_{1}\right)$ tidak dapat dibuktikan secara statistik.

\section{Hipotesis II}

Hasil estimasi pengaruh pada jalur Procedural Justice terhadap Employee Engagement diperoleh nilai path coefficients sebesar 0,208 yang memiliki arah positif. Sementara itu, nilai t-values pada jalur Procedural Justice terhadap Employee Engagement diperoleh nilai 2,042 dengan nilai p-values sebesar 0,042. Berdasarkan hasil tersebut, diketahui bahwa nilai $t$-values $2,042>1,96$ dan nilai $p$-values $0,042<0,05$ maka 
dapat disimpulkan bahwa terdapat pengaruh positif signifikan antara variabel Procedural Justice terhadap Employee Engagement pada karyawan PT X di Surabaya. Dengan demikian hipotesis kedua penelitian $\left(\mathrm{H}_{2}\right)$ dapat dibuktikan secara statistik.

\section{Hipotesis III}

Hasil estimasi jalur pada pengaruh antara variabel Distributive Justice terhadap Employee Engagement dengan mediasi Affective Commitment diperoleh besar pengaruh tidak langsungnya (indirect) 0,230 dengan nilai T-statistics 2,742 dan nilai p-value 0,006 . Mengacu pada hasil ini diketahui bahwa nilai T-statistics 2,742

$>\quad$ 1,96 dengan nilai $\mathrm{p}$-value $0,006<0,05$, maka dapat disimpulkan terdapat pengaruh tidak langsung signifikan antara variabel Distributive Justice terhadap Employee Engagement dengan mediasi Affective Commitment. Dengan demikian hipotesis ketiga $\left(\mathrm{H}_{3}\right)$ terbukti kebenarannya secara statistik. Pengaruh mediasi yang terjadi pada jalur Distributive Justice terhadap Employee Engagement bersifat full mediation karena pengaruh langsung (direct effect) antara Distributive Justice terhadap Employee Engagement $\left(\mathrm{H}_{1}\right)$ tidak disimpulkan signifikan.

\section{Hipotesis IV}

Hasil estimasi jalur pada pengaruh antara variabel Procedural Justice terhadap Employee Engagement dengan mediasi Affective Commitment diperoleh besar pengaruh tidak langsungnya (indirect) 0,286 dengan nilai T-statistics 2,900 dan nilai p-value 0,004. Mengacu pada hasil ini diketahui bahwa nilai $T$-statistics 2,900 > 1,96 dengan nilai pvalue $0,004<0,05$, maka dapat disimpulkan terdapat pengaruh tidak langsung signifikan antara variabel Procedural Justice terhadap Employee Engagement dengan mediasi Affective Commitment. Dengan demikian hipotesis keempat (H4) terbukti kebenarannya secara statistik. Pengaruh mediasi yang terjadi pada jalur Procedural Justice terhadap Employee Engagement bersifat partial mediation karena pengaruh langsung (direct effect) antara Procedural Justice terhadap Employee Engagement $\left(\mathrm{H}_{2}\right)$ juga disimpulkan signifikan. 


\section{KESIMPULAN DAN SARAN}

Berdasarkan rumusan masalah yang telah dianjukan, hipotesis, hasil analisis, dan pembahasan yang telah ada, maka diperoleh kesimpulan dalam penelitian ini yaitu sebagai berikut:

1. Distributive Justice berpengaruh langsung positif tidak signifikan terhadap Employee Engagement pada karyawan PT X di Surabaya.

2. Procedural Justice berpengaruh langsung positif signifikan terhadap Employee Engagement pada karyawan PT X di Surabaya.

3. Distributive Justice berpengaruh tidak langsung dan signifikan terhadap Employee Engagement melalui mediasi Affective Commitment pada karyawan PT X di Surabaya.

4. Procedural Justice berpengaruh tidak langsung dan signifikan terhadap Employee Engagement melalui mediasi Affective Commitment pada karyawan PT X di Surabaya.

\section{DAFTAR PUSTAKA}

Allen N J and Meyer J P. 1990. The Measurement and Antecedents of Affective, Continuance and Normative Commitment to the Organization. Journal of Occupational Psychology. Vol 63, No: 1, pp 1-18.

Campbell, N. S., Perry, S. J., Maertz, C. P., Allen, D. G., \& Griffeth, R.W. (2013). All you need is... resources: The effects of justice and support on burnout and turnover, Human Relations, 66(6), 759-782.

Colquitt, J.A. (2001). On The Dimensionality of Organizational Justice: A Construct Validation of A Measure. Journal of Applied Psychology, 86 (3), 386-400.

Colquitt, J. A., Lepine, J. A., \& Wesson, M., J. (2013). Organizayional Behavior: Improving performance and commitment in the workplace. International Edition $\left(3^{\text {td }}\right.$ ed.). New York: McGraw-Hill/Irwin Companies Inc.

Cropanzano, R., Bowen, D. E., \& Gilliland, W. S. (2007). The management of organizational justice, Academy of Management Perspectives, 21, 34-47.

Gallup (2017). State of the Global Workplace Report. Retrieved 
fromhttps://www.gallup.com/workplace/238079/state-global-workplace-2017.aspx

Greenberg, J. and Cropanzano, R. (1993). The Social Side of Fairness: Interpersonal and Informational Classes of Organizational Justice. Justice in the Workplace: Approaching Fairness in Human Resource Management, Lawrence Erlbaum Associates, Hillsdale (pp. 79-103).

Kahn,W.A. (1990). Psyochological conditions of personal engagement and disengagement at work, Academy of Management Journal, 33, 692-724

Li, A., \& Cropanzano, R. (2009). Fairness at the group level: Justice climate and intra unit justice climate, Journal of Management, 35(3), 564-599.

Macey, William H \& Schneider, Benjamin. (2008). The Meaning of Employee Engagement. Industrial and Organizational Psychologi, Vol 3 No 30, March 2008.

Markos, S. \& Sridevi, M.S. (2010). Employee engagement: the key to improving performance. International Journal of Business and Management, 5(12), 89- 96.

Meyer J and Allen N. 1997. Commitment in the Workplace: Theory, Research, and Application. Sage Publications.

Ologbo, A. C., \& Sofian, S. 2013. Individual and Organizational Factors of Employee Engagement on Employee Work Outcomes, Procedia - Social and Behavioral Sciences.3(3), 1-9.

Saks, A.M., (2006). Antecedents and Consequences of Employee Engament. Journal of Mangerial Psychology, 21 (7), 600-19.

Sugiyono. 2013. Metode Penelitian Kuantitatif Kualitatif dan R\&D. Bandung: CV. Alfabeta

Suliman, A., \& Khatairi, M. (2013). Organizational justice, commitment and performance in developing countries: The case of UAE, Journal Employee Relation, 35(1), 98-115.

Yean, T., \& Yusof, A. (2016). Organizational justice: A conceptual discussion,

Journal Social and Behavioral Sciences, 219, 798-803.

Yulianti, P. (2016). Procedural Justice, Organizational Trust , Organizational Identification Dan Pengaruhnya Pada Employee Engagement, (3), 210-225 